\title{
An Assessment of Revenue Mobilization in Nigeria Local Government: Problems and Prospects.
}

\author{
Raphael Adekola Dada \\ Department of Accounting \\ Ekiti State University. Ado-Ekiti, Nigeria \\ Isaac Adesodun Adebayo \\ Department of Accounting \\ Ekiti State University. Ado-Ekiti, Nigeria \\ Ogunmakin Adesola Adeduro \\ Department of Accounting \\ Ekiti State University. Ado-Ekiti, Nigeria
}

\begin{abstract}
This study assessed the prospects and problems of revenue mobilization in Nigerian Local Governments. It specifically determined the significant impact of development on internally generated revenue of local government in Nigeria; assessed the impact of financial misappropriations on internally generated revenue in the local government in Nigeria. The study employed the use of closed ended and likert scale ranked, wellstructured questionnaire as the source of data collection. The responses of the questionnaire were coded and later analyzed with the use of inferential (multiple regression) statistics. The study revealed that development has significant impact of $21.9 \%(t=3.575$ and $p<0.05)$ on internally generated revenue of local government in Nigeria, while financial misappropriation has significant impact of $26.5 \%(t=4.668$ and p<0.05) on internally generated revenue of local government in Nigeria. The study concluded that the level of development (human and infrastructural) and the rate of financial misappropriation are determinants to the revenue base of Nigerian local governments. It is recommended that Nigerian local government authorities should ensure both human and infrastructural development in their respective constituencies as this is influential on the level of revenue derivation. In addition, local government authorities should ensure a carrot and stick approach whereby members of staff are rewarded on performance and strictly punished for perpetrating financial misappropriations in other to curb the menace of the anathema on the fabric of the society.
\end{abstract}

Key words: local government, revenues mobilization, revenue allocation, sources of revenue

\section{INTRODUCTION}

The need to catalyze balance development, maximize citizens' participation and arouse government responsive necessitates the creation of local government. The local government serves as a form of political and administrative structure facilitating decentralization, national integration, efficiency in governance, and a sense of belonging at the grassroots (Adedokun, 2012). The local government is a unit of administration all over the world and a critical tier of government because of its closeness to the people (Gboyega, 1987; Agagu, 2004). Local government also appears to both the people and government as intermediary institution that relays the opinions and demands of the grassroots to a higher government (Lawal and Abegunde, 2010). 
Local governments in Nigeria are potentially very important for social and economy roles that the constitution bestows on them as they play a significant role in generating revenue and encouraging civil involvement, as well as creating a visible link between taxes and service delivery. According to Uhunmwuangho \& Epelle (2008), every local jurisdiction has its unique economic, social and physical characteristics and its historical tradition which are better understood by its people. Thus, the Local Government Areas are created to provide the services which the Federal and State Governments cannot easily undertake due to their remoteness from the local communities. Fosu (2012), outlines the importance of local revenue to Local Governments as follows: Financing administration costs; Financing maintenance costs and thus promoting ownership of projects; Permits collection of localized and low yielding revenues; Guarantees sustainability of service delivery and autonomy of local governments; Regulates businesses and provides important infrastructure and services such as markets and public conveniences at a charge; Reduces pressure on central governments and reliance on donors.

But various studies as Olusola, (2011); Akindele and Obiyan,(2002) and Ekpo and Ndebbio (1998), have shown that local governments in Nigeria depend solely on statutory allocations from the federal government. In recent times, Nigerians has been experiencing a dwindling pattern in the federal allocation because most of the federal government revenue is from petroleum proceeds. There is less demand for petroleum in the world market as others developed nations of the world are shifting away from petroleum as major sources of energy. Then, the obligation lies on the local government to work on their internal revenue efforts to be able to accomplish its goals in the local community. Local governments now face more challenges in terms of struggling to be less dependent on the Federal and the state governments for financial resources. Though, there various allocation system mandates that a certain fraction of the Federation Account be allocated to local governments, these funds are not enough to meet expenditure requirements, since it's from oil proceed that has witness dwindling over a year ago which the Nigeria Government still find it difficult to meet her obligations (Olusola, 2011),. The problem of lack of fiscal transparency as a result of mismanagement of funds, corruption, poor internal control, lackadaisical attitude to government work and property still abounds. The question that comes to mind is that if the statutory allocation is not forthcoming, if oil is de-emphasized in the economy what would be the lot of local governments? How are they to survive if this should occur? Hence, this study examines the areas and ways of boosting internally generated revenue of local governments in Nigeria and assess the impact of internal generated revenue on the local government revenues (Lawa, 2010; Agbu, 2004).

The 1979 constitution empowered the national Assembly to determine what proportion of the federation account and revenue from a state to be allocated to the local government. In 1981, the National Assembly fixed these proportions at 10percent of the federation account and 10 percent of the total revenue of the state. In 1985, the state's proportion still remains at 10 percent of the internally-generated revenue; local governments' allocation from the federation account was later adjusted to 20 percent.

It was further increased to 25 per cent with the arguments that local governments are expected to take on larger developmental responsibilities. The revenue allocation has continued to vary in proportion over the years. At present, local government receive 20 per cent share of the federation account. In addition, proceed from the value added tax (VAT) are also allocated to them. 
Ekpo and Ndebbio (1998) stated that in 1976, local government reforms states that the internal revenue sources of local governments includes: Rates, which include property rates, education rates and street lighting; Taxes such as community, flat rates and poll tax; Fines and fees, which include court fines and fees, motor park fees, forest fees, public advertisement fees, market fees, regulated premises fees, registration of births and deaths and licensing fees; and Miscellaneous sources such as rents on council estates, royalties, interest on investment and proceeds from commercial activities.

\section{OBJECTIVES OF THE STUDY}

The broad objective of the study is to assess the prospect and problems of revenue mobilization in Nigeria local governments. However, the specific objectives were:

i. determine the significant impact of development on internally generated revenue of local government in Nigeria;

ii. assess the impact of financial misappropriations on internally generated revenue in the local government in Nigeria.

\section{RESEARCH QUESTIONS}

The following research questions were raised to pilot the research work.

a) Does development have significant impact on local government internally generated revenue in Nigeria?

b) What effect do financial misappropriations have on the effective realization of internally generated revenue?

\section{Conceptual Clarifications}

The term revenue generation in Nigeria local governments is basically derived from tax and non-tax sources. Agya, Ibrahim and Emmanuel, (2015); Abubakar (1999) stated that revenue is a general term for all monetary receipts accruing from both tax and non tax sources as well as fees, grants and contributions constitute the live wire of the local government. Olaoye (2008) viewed tax as a system of imposing compulsory levy on all income, goods, services and properties of individuals, partnership, trustees, executors and companies by the government. Tax itself is an amount of money that you must pay to the government according to your income, property, goods that is used to pay for public services and perform other social responsibilities (Olatunji, Olaleye, and Adesina 2001). While non-tax is the revenue accruing to the government other than tax and which is supported by law of the Federation. The history of man has shown that man has to pay tax in one form or the other that is either in cash or in kind, initially to his chieftain and later on a form of organized government (Ojo, 2003). Based on the above clarification, no system or rules can be effective whether foreign or native unless it enjoys some measures of financial independence.

\section{Purpose of Local Government}

Yahaya (1999) gave an abridgment of the responsibilities charged on local government to include: Bringing people closer to the government by setting up local administration to perform local functions, representing local interest to State and Federal Governments. Also there is need for local government to mobilize resources in order to take care of the responsibilities to the people and based on the constitution the sources of Nigeria local government are group into (Agya, et al, 2015): external sources which includes; Statutory allocation from the Federation Account in accordance with section 160 (2) of the constitution of the Federal Republic of Nigeria (Promulgation) Decree 1989, Statutory allocation from each state government to the local governments in its areas of jurisdiction, Federal Grants-in-aid, State-Grants-in-aid, Borrowing from state government and other financial institutions. According to Atakpa, Ocheni and Nwankwo (2012), Statutory allocations from the Federation 
Account plays a highly increasing roles in the proportion to the revenue generated by local governments in Nigeria. However, even the oil boom and revenue accruing to the Federations' Account started declining since 1983. With this dwindling of revenue sources to the local governments in Nigeria, it implies that local governments in the country should seek for more green pastures in their respective locality to increase their internal revenue generation, if they are to execute their numerous responsibilities and programs to their people. Internal sources which are the internally generated revenue that formed a greater bulk of the total revenues accruing to the local governments before 1976. With the 1976 Local Government Reforms, revenue sources were further widened to enable the local governments to internally generate enough funds/revenues to discharge their development and civil responsibilities. Consequently, the constitution of the Federal Republic of Nigeria 1999 CAP C23 L.F.N. 2004 specifically states the types of internally generated revenue that are exclusive to the local government councils. Prominent among these revenues are: Community Tax/Community Rates, Property (Tenement) Rates, General/Development/Capitation Rates, Licenses, Fees and Charges (Advertisement fees, Baker houses licenses, Beggar minstrel fees, Bicycle licenses/hire permits, Births and deaths registration fees, Brick making and block industry licenses, Cigarette sales licenses, Burial fees and charges on local government burial grounds, Cart/truck licenses, Cattle dealers/Butchers licenses, Contractors registration fees), Dog licenses, Fishing/hunting fees, Forestry and fuel/fire wood exploitation fees, Goldsmith's licenses, Hawkers permits/licenses, Hunting licenses, Local liquor brewing/sales licenses, Marriage registration fees, Minor/small/cottage industries licenses, Control of noise licenses, Palm wine fees, Pit sawing licenses, Produce (palm oil/kernel) buying/sales licenses, Rents and plot fees (from Landlords), Retail trade licenses, Slaughter fees, Interest on Revenues (Interest on state deposits, Interests on investments, Profits from sale of investments/stocks, shares, etc.), Departmental Recurrent Revenues (Survey fees - from the Department of Works \& Planning, Repayment of personal advances, Refund of salaries and/or allowances, Refund of subsistence of students in training, Re-imbursement of state witnesses expenses, Sales of library books and literature, Nursery school and day-care centers fees, Conservancy or compost charge, Sale of produce e.g. palm oil/kernel, Profit on local government farm accounts, Tractor/grader/caterpillar hire fees, Irrigation fees, Sale of firewood, Sale of timber, Sale of produce, Cattle/goat/sheep/poultry treatment charges, Fodder, Stray animal poundage fees, Workshop repairs receipts, Sale on stores. Based on those item mentioning above, it can be inferred that local government in Nigeria have various sources of revenues opened to them but many of these various sources are either untapped or under-tapped in most of our local government areas of Nigeria.

\section{Problems of Internal Revenue Generation in Nigerian Local Governments}

Bahl and Smoke (2003) state that one major administrative problem experienced today by several councils in Africa are their inability to collect fully the revenue due to them and in many Local Government/municipal, there are huge gaps between actual and projected revenues. Several reasons have been responsible for low and unsatisfactory internal revenue generation. The following are the major factors responsible for the low and poor mobilization of revenues in the Nigeria local governments as identified by Adedokun (2007); Atakpa, Ocheni; Nwankwo (2012) and Agya, et al. (2015):

Shortage of well trained and qualified personnel which supposed to serve as tool for collection of taxes and rates at the local level, even the few available are not properly groom/trained in efficient budgetary and financial management systems;

Lack of commitment on the part of revenues collector, this is based on the fact that most of the revenues collectors are totally dishonesty and this was affirmed during our survey that many 
of the revenues collectors have their own receipt booklet different from official one while they issue their own receipt for the huge amount and pay a token to the purse of local government and this really affects the internal generating revenue of the local government;

Defects in the revenues collecting machinery and some of the laws for revenues collection in Nigeria local government have not been updated by various state governments especially in areas of rating, tenement rates and the death registration fees which has remained untapped for long dues to the tradition and the culture of our land;

Familiarity between the revenue collectors and the people of the council areas: There is no doubt that the revenue collector and the resident of the council areas are related in one way or the other while some are even blood related as they will not like to tax's or collect money from their father, mother, in-laws, brothers, sisters and friends of theirs. This act has dwindled the amount of revenues that goes into the purse of the local government council;

Lack of proper record; there is no doubt that the local government administer taxes, determining taxable property values, calculating and distributing property tax bills and applying tax enforcement against non-payers, but failed in the responsibility for maintaining property and ownership records, managing receipt payment and keeping the valuable records; Lack of realism on the part of State Government which could be observed that there exist variations in the pattern of state allocations to Local Governments (Fjeldstad and Heggestad 2012).

Also Egonmwan (1984), stated that the problem of local government revenue generation have been compounded by the fact that the state governments have acquired the more lucrative, elastic and collectable revenue sources (e.g. water rates, motor vehicle license fees, form building plans), leaving local government with taxation with low ceilings, revenue which are administratively and politically difficult to exploit in an environment where the vast majority of the people are poor, self-employed and dispersed in rural areas. Another constraint is imposed on local government revenue mobilization capacity through state control over local government budget, which is made to pass through many levels of approval in the hands of the state government. Even after approval, post-budget controls still impose further restrictions on what local governments can do (Roberts, 1998).The delay in the passage of annual budget for local governments poses a great problem in the sense that budget sometimes take 3 months before approval. Inadequate data on all economic activities in the district e.g. hairdressers, seamstresses, traders, barter, lotto kiosk; Misclassification of properties and Business and Inappropriate tax assessment basis; Lack of realistic means of accessing the revenue potentials due to lack of accurate data; Revenue collectors not paying to the council all monies collected and the absence of tracking mechanisms; Property owners avoiding the payment of property rates; Some individuals and small-scale enterprises engaged in economic activities avoid the payment of taxes to the council; Laborious and time consuming business licensing and permit acquisitions therefore deter small scale business operators (Collin and Ashiaghor, 2012).

\section{Prospects of Local Governments Revenues Mobilization in Nigeria}

The local government revenue in Nigeria can be increased if the existing legal sources of revenue are fully exploited and tapped, most local governments will need not to rely on or bother itself seeking additional sources since the present sources provided by the existing laws will be well adequate to meets the obligations (Agya, et al. 2015 \& Atakpa, Ocheni \& Nwankwo, 2012). Revenue generation can also be increase through the following: facilitating arrangement between the council official and the traditional ruler on how to collect community rates and involvement of traditional rulers through the head of the villages and their chiefs to 
assist in collection of the tax on behalf of the local governments due to their familiarity with and respect accorded to them by their subject (Olaoye, 2008); modification of existing laws on internal generating revenues to enhance their generation capacity; promulgating laws that will enhance zero tolerant for corruption, because irrespective of huge amount of revenues generated internally in our local governments, no valuable progress will be made or achieved if the incessant misappropriation, mismanagement, corruption and embezzlement of public funds is not seriously dealt with (Atakpa, el at. 2012); Investing of the surplus funds of local government in Nigeria in venture such as poultry/fish pound, building of hostels in our tertiary institutions, transportation that will yield them regular revenues, apart from investing on stock and share which can crash at any time like what we are experiencing now; staff motivation Olorungbemi (2015) opined that revenue collectors should be financially or otherwise motivated to discourage them from tampering with council money or colluding with the members of the public to defraud the council of it revenues, which can be done through training and retraining to enhance their knowledge and adequate remuneration and bonus based on revenue collected; Adequate Staffing of Local Government secretariat with qualified and well training hands devoid of questionable integrity to enhance internally generating revenues(Ifeayekwu, 2015); engagement of the use of prevention and detection methods/techniques such as stringent penalties that will forestall the forging of receipts and non-remittance of revenue collected connivance of the revenue collectors with the members of the revenue paying public which results to illegal exemption of some revenue payers by revenue collectors ,under-assessment of the revenue payers (Atakpa, el at. 2012).

\section{METHODOLOGY}

This study adopted the use of survey research design as its research strategy. The population of the study comprised all members of staff of treasury section, accounting section, internal audit section, rate section in the sixteen (16) Local Government Areas, Ekiti-State, Nigeria. They were selected due to the fact that they are sub-set of all the Local Government Areas in Nigeria and were relevant to provide answers to questions of the study, purposive sampling techniques was employed and sample size of three hundred (300) respondents were selected. Closed ended and likert scale ranked well-structured questionnaire titled an assessment of revenue mobilization in Nigeria Local Government was designed to capture the demographic details of respondents and their opinion with respect to the research questions, five variables of Strongly Agreed (SA), Agreed (A), Strongly Disagree (SD), Disagree (D) and Indifference (ID) were adopted with likert scale of 5,4,3,2 and 1 respectively for the variables. The responses were coded and later analyzed with the use of multiple regressions.

\section{Table1: Model summary}

\section{RESULTS AND INTERPRETATION}

Table 1: Combined Regression Analysis (Development and Financial Misappropriation) on Internally Generated Revenue

\section{Model Summary}

\begin{tabular}{|c|c|c|c|c|}
\hline Model & $\mathrm{R}$ & R Square & Adjusted R Square & $\begin{array}{l}\text { Std. Error of the } \\
\text { Estimate }\end{array}$ \\
\hline 1 & $.203^{\mathrm{a}}$ & .041 & .038 & 1.04300 \\
2 & $.327^{\mathrm{b}}$ & .107 & .101 & 1.00842 \\
\hline
\end{tabular}

a. Predictors: (Constant), Development

b. Predictors: (Constant), Development, Financial Misappropriations 
Table 2: Combined Regression Analysis (Development and Financial Misappropriation) on Internally Generated Revenue

ANOVA $^{\mathrm{a}}$

\begin{tabular}{|c|c|c|c|c|c|}
\hline$\overline{\text { Model }}$ & Sum of Squares & $\overline{d f}$ & Mean Square & $\bar{F}$ & Sig. \\
\hline Regression & 13.900 & 1 & 13.900 & 12.7 & $.000^{\mathrm{b}}$ \\
\hline Residual & 324.180 & 298 & 1.088 & \multirow{5}{*}{$30^{17.7}$} & \multirow{5}{*}{$.000^{\mathrm{c}}$} \\
\hline Total & 338.080 & 299 & & & \\
\hline Regression & 36.060 & 2 & 18.030 & & \\
\hline Residual & 302.020 & 297 & 1.017 & & \\
\hline Total & 338.080 & 299 & & & \\
\hline
\end{tabular}

a. Dependent Variable: Internally Generated Revenue

b. Predictors: (Constant), Development

c. Predictors: (Constant), Development, Financial Misappropriation

Table 3: Combined Regression Analysis (Development and Financial Misappropriation) on Internally Generated Revenue

Coefficients $^{\mathrm{a}}$

\begin{tabular}{|c|c|c|c|c|c|c|c|c|}
\hline \multirow{2}{*}{\multicolumn{2}{|c|}{ Model }} & \multicolumn{2}{|c|}{$\begin{array}{l}\text { Unstandardized } \\
\text { Coefficients }\end{array}$} & \multirow{2}{*}{\begin{tabular}{|c|}
$\begin{array}{l}\text { Standardized } \\
\text { Coefficients }\end{array}$ \\
Beta
\end{tabular}} & \multirow{2}{*}{\multicolumn{2}{|c|}{$\mathrm{T}$}} & & \multirow[t]{2}{*}{ Sig } \\
\hline & & B & Error & & & & & \\
\hline & (Constant) & 3.184 & .258 & & 350 & 12 . & ) & .00 \\
\hline 1 & Development & .219 & .061 & .203 & & 3.5 & 0 & .00 \\
\hline & (Constant) & 3.053 & .251 & & & & & .00 \\
\hline 2 & Development & .006 & .075 & .005 & 6 & & 0 & .94 \\
\hline & $\begin{array}{l}\text { Financial } \\
\text { Misapproprition }\end{array}$ & .265 & .057 & .323 & & 4.6 & 0 & .00 \\
\hline
\end{tabular}

a. Dependent Variable: Internally Generated Revenue

Based on the table 2 above the equation for the regression model is expressed as:

$$
\mathrm{Y}=\mathrm{a}+\beta 1 \mathrm{X} 1+\beta 2 \mathrm{X} 2+\varepsilon
$$

$Y=0.198+0.266 \times 1-0.253 X 2+\varepsilon$

Where

$\beta$ is a correlation coefficient

$\mathrm{Y}=$ Internally Generated Revenue

$\mathrm{X} 1=$ Development

$\mathrm{X} 2=$ financial misappropriations

$\varepsilon=$ Error Term 


\section{RESULTS AND DISCUSSION}

Based on the result in table1 below, there is $20.3 \%$ level of relationship between the internally generated revenue and the level of development in the selected local government areas and the level of significance as depicted in the table 5 , indicate that there is positive level of significant relationship between level of development in local government in Nigeria and the level of its internally generated revenue $(\mathrm{r}=0.203, \mathrm{p}=0.000<0.05)$. Also in table 1 , the result showed that $32.7 \%$ relationships exist between Financial Misappropriations and internally generated revenue and based on the correlation result in table6, there is a positive significant relationship between Financial Misappropriations and internally generated revenue ( $\mathrm{r}=0.327$, $\mathrm{p}=0.000<0.05$ ). Based on the table1, the development of local government determines $4 \%$ variation in internally generated revenue by the local government, while financial misappropriation determines $10.7 \%$ variation in internally generated revenue of local government. The Anova result which indicated the significance of the Development and Financial misappropriation in explaining the variation in explanatory variable (Internally generated revenue), shows that the Development and Financial misappropriation significantly explains Internally generated revenue of the selected local government (F-cal= 12.778 and 17.730 respectively, $\mathrm{p}<0.05$ ). In the table 4.3 it could be inferred that the unstandardised and standardized beta coefficient of Development(excluding) are 0.219 and 0.203 as $t=3.575$ and $\mathrm{p}<0.05$. This implies that the internally generated revenue of a local government will increase by $21.9 \%$ for every one unit increase in the level of its development and highly significant because its $\mathrm{p}$ value $(0.000)$ is lesser that $5 \%$ level of significance. In relation to Financial Misappropriation, it indicated an unstandardised and standardized beta coefficients of 0.265 and 0.057 respectively with $t=4.668$ and $p<0.05$. This means that an increase in the level of financial misappropriation in revenue collection increase the level of internally generated revenue by $26.5 \%$, which implies that revenue collectors in local government are motivated to collect revenue based on the amount they will siphon-off from the revenue collected for the government.

\section{CONCLUSION AND RECOMMENDATIONS}

The study concluded based on the findings that the level of development (human and infrastructural) and the rate of financial misappropriation are determinants to the revenue base of Nigerian local governments. It is recommended that Nigerian local government authorities should ensure both human and infrastructural development in their respective constituencies as this is influential on the level of revenue derivation. In addition, local government authorities should ensure a carrot and stick approach whereby members of staff are rewarded on performance and strictly punished for perpetrating financial misappropriations in other to curb the menace of the anathema on the fabric of the society.

\section{References}

Abubakar Halidu (1999) National Orientation Workshops For Local Government Councilors Training Manual P. 8

Adedokun, A. (2012) Local Government Tax Mobilization and Utilization in Nigeria:

Problem and Prospects: http:/www./visar.csustan.edu/aaba/Adedokun.pdf Retrieved on September 18, 2016

Agagu, A. (2004). Continuity and Change in Local Government Administration and the Politics of Underdevelopment. In: Agagu, A. \& Ola, R. (eds). Development Agenda of Nigeria State. Ibadan: Fiag Publishers.

Agbu, Osita (2004) "Re-inventing Federalism in Post-Transition Nigeria: Problems and Prospects". African Development, XXIX(2), , pp.26-52.

Agya, A. A., Ibrahim, Y. M. and Emmanuel, E. (2015). Internal Revenue Generation in the Taraba State, Nigerial: Problems and Prospects. International Journal of Economics, Commerce and Management. III(2).1-13 
Akindele, S.T, Olaopa, O.R \& Obiyan, A.S. (2002). Fiscal Federalism and Local Government Finance in Nigeria" International Review of Administrative Sciences. 68(4): 557 - 577.

Atakpa M., Ocheni S. \& Nwankwo C.B. (2012) "Analysis of options for Maximizing local government internally generated Revenue in Nigeria". International journal of learning \& Development ISSN 2164-4063 2012, vol. 2, No. 5

Bahl, R. \& Smoke, P. (2003) Restructuring Local Government Finance in Developing Countries. Lessons from South Africa (Cheltenham: Edward Elgar).

Collins Fosu and George Ashiagbor.(2012) "Application for local government revenue mobilization". Proceedings of Global Geospatial Conference

Egonmwan, J. A. (1984). Principles and Practice of Local Government in Nigeria.Benin City

Ekpo A. H. and J. Ndebbio (1998) "local government fiscal operation in Nigeria”. AERC Research Paper

73, African Economic Research Consortium, Central Bank of Nigeria Statistical BulletinVol. 20 December 20052009 Nairobi

Federal Republic of Nigeria. 1999. The constitution of the federal republic of Nigeria. Lagos. Government printer.

Fjeldstad O. H. and Heggestad K. (2012) local Government Revenue Mobilisation in Anglophone Africa. Chr. Michelsen Institute working paper (WP 2012:6)

Fosu M. A. (2012) An Evaluation of Effectiveness of Revenue Mobilization Strategies of Metropolitan, Municipal and District Assemblies (MMDAS) in Ghana, a Case Study of Kumasi Metropolitan Assembly (KMA)

Gboyega A. (1987) “local government reform in Nigeria”.In P. Mawhood ed., local Government in the third world. John Wileysons: London.

Ifeayekwu, F. C. (2015). The Problems and Prospects of Revenue Generation in Nigerian Local Government System: A Study of Njikoka Local Government Area, 1999-2012. A Thesis submitted to the Department of Political Science, University of Nigeria, Nsukka in Partial Fulfilment of the Requirements for the Award of Master of Science (M.Sc.) Public Administration

Lawal T. and Abegunde 0. (2010) Local Government, Corruption and Democracy in Nigeria. Journal of Sustainable Development in Africa vol. 12, no 5.

Olatunji L. A., Olaleye M. O. and Adesina O. T. (2001) "principle of taxation in Nigeria", mighty babs productions, monatan, Ibadan

Olorungbemi S. T. (2015) Revenue Generation and Local Government Administration in Nigeria (1999-2007):The Case of Ijumu Local Government Area of Kogi State. International Journal of Business and Social Science. 6(10), 137-159

Olusola, O. O. (2011) Boosting Internally Generated Revenue of Local Government in Ogun State, Nigeria (A Study of Selected Local Government in Ogun State), European Journal of Humanity and Social Sciences 8(1), 336-348

Robert F.O.N (1998) Paper presented at a Two-days workshops on Effective Budgeting, Planning, Implementation and Evaluation for the Ten Local Council in Oke-Ogun Area of Oyo State, Iseyin.

Uhunmwuangho, S.O. \& Epelle A. (2008). Strategies for Managing Challenges and Ensuring Effective Governance in Local Governments in Nigeria, Nigerian Benin, Journal of Citizenship Education Vol.7 No.2.

Yahaya A.M. (1999) Lecture Notes On Public Finance Kaduna Polytechnic P. 36. 